Vol. 4: 385-395.

\title{
Sugars and organic acids in clones and cultivars of arctic bramble and hybrid. Sensory evaluation of juices and jellies
}

\author{
Sari Häkkinen, Harri Kokko and Sirpa Kärenlampi \\ Department of Biochemistry and Biotechnology, University of Kuopio, FIN-70211 Kuopio, Finland \\ Sirpa Paasisalo \\ Department of Ecology and Environmental Science, University of Kuopio
}

\begin{abstract}
Arctic bramble (Rubus arcticus L.) and its hybrid (Rubus arcticus L. nothosubsp. stellarcticus $\mathrm{G}$. Larsson) are both cultivated in Finland. Sugars and major organic acids were analysed in several arctic bramble clones and cultivars $(n=19)$ and arctic bramble hybrids $(n=5)$ by gas chromatography. The main sugar in the berries was sucrose, and the main organic acid was citric acid. The average total contents of sugars in the berries of arctic brambles and arctic bramble hybrids were $5.0 \mathrm{~g}$ $(\mathrm{CV}=0.1)$ and $4.7 \mathrm{~g}(\mathrm{CV}=0.2)$ per $100 \mathrm{~g}$ of fresh weight, respectively. The average total contents of organic acids in the berries of arctic brambles and arctic bramble hybrids were $0.6 \mathrm{~g}(\mathrm{CV}=0.3)$ and $1.5 \mathrm{~g}(\mathrm{CV}=0.5)$ per $100 \mathrm{~g}$ of fresh weight, respectively. Changes in these compounds during the harvesting period were also studied in mixed samples. Moreover, the sensory properties of juices and jellies prepared from several arctic bramble clones were evaluated by quantitative sensory profiling. The sugar/acid ratio obtained from the chemical analyses of the berries was compared with the sensed sweetness and sourness of juices and jellies.
\end{abstract}

Key words: Rosaceae, berry clones, gas chromatography

\section{Introduction}

The wild arctic bramble, Rubus arcticus L. (also called Rubus arcticus ssp. arcticus), grows and produces fruits in the circumpolar subarctic zone of the northern hemisphere. Because of its aroma, this 'Arctic Ruby' is a valuable berry, and the first investigations aimed at its cultivation were initiated in Finland back in the 1930s. Since then, many aspects relating to its ecology, morphology, pollination, berry production and cultivation have been explored (Larsson 1970, Ryynänen 1973, Kangasjärvi and Oksanen 1989). The berries of arctic bramble are dark red or reddish brown and have an exceptionally pleasant and strong aroma which clearly differs from that of other berries or fruits. The berries are in great demand as raw material for the food and wine industries. In Finland, the best-known product is the liqueur 'Mesimarja'. The aroma of the berries has been extensively studied (Kal- 


\section{Häkkinen, S. et al.: Sugars and organic acids in arctic bramble}

lio 1975, Kallio 1976a, Kallio 1976b, Kallio and Honkanen 1974, Kallio et al. 1984), and more than 70 compounds have been identified, 2,5dimethyl-4-methoxy-2H-furan-3-one and 2,5dimethyl-4-hydroxy-2H-furan-3-one being the predominant ones (Kallio 1976, Pyysalo et al. 1977).

Arctic bramble has, however, a number of characteristics which would appear to preclude its economic cultivation. Investigations have, therefore, been carried out on the feasibility of using Rubus stellatus Sm. (also called Rubus arcticus ssp. stellatus), Alaskan arctic bramble, as a breeding partner for arctic bramble, since these two species are closely related and can be crossed without difficulty (Larsson 1969). The cultivability of the new hybrid selections - here called arctic bramble hybrids - is distinctly better than that of arctic bramble. The longer shoots facilitate picking, the yield is notably better than that of the arctic bramble clones studied earlier, and there is some increase in the size of the berries (Hiirsalmi and Säkö 1980). Unfortunately, the hybrid retains only a fraction of the aroma of arctic bramble (Hiirsalmi et al. 1974). Kallio et al. (1980) found that the contents of the aroma compounds of the hybrid ranged from 30 to $80 \%$ of the respective concentrations in arctic bramble.

According to Burton (1982), the flavour of fruits is largely affected by sugars, organic acids and aroma constituents. Postharvest changes in flavour are usually due to an increase in sugars and aroma constituents and a decrease in acidity. Sistrunk and Morris (1985) noted that colour is more stable in strawberries with higher levels of acids. Although sugar and acid concentrations may vary among different cultivars, the most common organic acids in fruits and berries are citric acid and malic acid (Ulrich 1970). The malic acid/citric acid ratio can be used to estimate the ripeness of fruit because the ratio usually increases during ripening.

The principal keto acids in arctic bramble are 2-oxoglutaric, pyruvic, oxaloacetic and glyoxylic acids (Kallio et al. 1978). The main sugars in the strains, cultivars and hybrids of arctic bram- ble are glucose, fructose and sucrose, and the main acids are citric and malic acids (Kallio et al. 1985).

Arctic bramble is self-sterile (Tammisola and Ryynänen 1970, Tammisola 1988), and in order to fruit it must grow as a population of two or more clones. Thus far, only two cultivars, 'Mespi' and 'Pima', have been commercially available. In the present study, the contents of the main sugars and organic acids in the berries of 24 clones and cultivars of arctic bramble and arctic bramble hybrid were analyzed. The organic acids and sugars were also assayed on fresh, mixed 'Pima' and 'Mespi' samples harvested at different dates in August to study the changes during the harvesting period. Moreover, juices and jellies made from several arctic bramble clones were sensorially evaluated, and comparisons were made between the chemical analyses and sensory parameters.

\section{Material and methods}

\section{Chemical analyses of arctic brambles and arctic bramble hybrids}

\section{Harvesting of berries}

The arctic bramble cultivars 'Mespi' and 'Pima' originate from the Agricultural Research Centre, North Savo Research Station (Maaninka, Finland) (Ryynänen 1972, Ryynänen and Dalman 1983). The arctic bramble clones were collected from different parts of Finland (Tammisola 1988) and are possible candidates for new cultivars. The arctic bramble hybrid cultivars 'Sofia', 'Anna' and 'Linda' were from the Swedish Agricultural University, Röbäcksdalen, where they were developed by Dr Gunny Larsson (Larsson 1969, Kotimäki and Hiirsalmi 1979). The arctic bramble hybrid cultivars 'Aura' and 'Astra' have been described by Hiirsalmi et al. (1987).

Fresh, mixed berries of the arctic bramble (Rubus arcticus L.) cultivars 'Pima' and 'Mespi' were collected from the Botanical Garden of 


\section{AGRICULTURAL SCIENCE IN FINLAND}

Vol. 4: 385-395.

the University of Kuopio at different dates in August 1993, and the samples were analysed within two days. Berries from 'Pima', 'Mespi' and 17 arctic bramble clones and five arctic bramble hybrid (Rubus arcticus L. nothosubsp. stellarcticus G. Larsson) cultivars ('Aura', 'Astra', 'Linda', 'Anna' and 'Sofia') were collected from two experimental fields at Muuruvesi, eastern Finland, during the period July 22 August 24, 1993. The berries of each clone and cultivar harvested at different dates were pooled and stored at $-25^{\circ} \mathrm{C}$ until analysed $(7$ months later). Frozen samples were thawed at $+20^{\circ} \mathrm{C}$ for $2 \mathrm{~h}$ before analysis.

\section{Analysis of sugars and organic acids}

The extraction method described by Haila et al. (1992a) for sugars and organic acids was applied as follows: The berries (c. $100 \mathrm{~g}$ ) were homogenized with a blender (Ultra Turrax, Janke \& Kunkel GmbH \& Co., Germany). Part of the homogenate, corresponding to $5 \mathrm{~g}$ of berries, was immediately extracted twice with $80 \%$ ethanol $(15$ and $5 \mathrm{ml})$ at room temperature by mixing with a blender (Ultra Turrax) for $2 \mathrm{~min}$. The combined extracts were centrifuged at $1400 \mathrm{~g}$ for 10 min. Recoveries with this extraction method were 94-97\% for sugars and 91-95\% for acids.

Derivatization of the sugars and organic acids was performed with N,O-bistrimethylsilyltrifluoroacetamide using the method of $\mathrm{Li}$ and Schuhmann (1980). The derivatives were identified and quantified by gas chromatography (GC) using a Varian Aerograph series 1400 gas chromatograph (Varian Association, USA) equipped with a flame ionization detector, a Varian 4270 integrator, and a glass column $(1,95$ $\mathrm{m} \times 0,085$ " i.d.) packed with $3 \% \mathrm{OV}-1$ on Gas Chrom Q. Operating conditions were as follows: injection port $260^{\circ} \mathrm{C}$, detector $300^{\circ} \mathrm{C}$, column $1 \mathrm{~min}$ at $170^{\circ} \mathrm{C}$, then $10^{\circ} \mathrm{C} / \mathrm{min}$ to $200^{\circ} \mathrm{C}, 6^{\circ} \mathrm{C} /$ min to $290^{\circ} \mathrm{C}$ and finally $2 \mathrm{~min}$ at $290^{\circ} \mathrm{C}$. Nitrogen was used as the carrier gas $(30 \mathrm{ml} / \mathrm{min})$. Hydrogen flow was $40 \mathrm{ml} / \mathrm{min}$ and air flow was $300 \mathrm{ml} / \mathrm{min}$. The volume of sample injected was $1 \mu \mathrm{l}$.

A mixture of reference compounds and the internal standard were analysed parallel to the samples to identify and quantify the peaks produced by the samples. D-Fructose and citric acid were purchased from Merck (Germany), D-glucose from BDH Chemicals Ltd. (UK), D-sucrose from Riedel -de Häen (Germany) and L-malic acid from Fluka (Switzerland). Phenyl-B-D-glucopyranoside (Sigma, USA) was used as an internal standard for the quantification of sugars and organic acids. Two identical samples (corresponding to $5 \mathrm{~g}$ of berries) from one homogenate were extracted and analysed. The analysis was repeated in duplicate in case the coefficient of variation of the results of these two samples was too high (usually over $10 \%$ ).

\section{Sensory evaluations}

\section{Preparation of juices and jellies}

Juices were prepared from two bramble cultivars ('Mespi', 'Pima') and eight clones (004, 021, $033,039,050,057,077,146)$ with the cold-press method (TUPU 3, Lohjan Mehumetalli, Finland) using pectinase enzyme (Pectolase number 102, Gist-Brocades, France; c. $1.0 \mathrm{ml}$ enzyme/1 kg of berries) to improve the yield of juices. The juice samples to be evaluated consisted of $35 \%$ cold-pressed juice and $10 \%$ sucrose. The jellies from the arctic bramble cultivars and clones ('Mespi', 'Pima', clones 004, 021, 033, 039, 050, 077,146 ) were prepared using $30 \%$ cold-pressed juice, $30 \%$ sugar and pectin (Genu pectin, type LM102AS, Kopenhagen pectin A/S, Denmark) as the gelatinizing agent.

\section{Soluble dry matter and $\mathrm{pH}$ of juices}

Before sucrose dissolved in water was added, the $\mathrm{pH}$ of the juices was measured. Soluble dry matter $\left({ }^{\circ}\right.$ Brix) was measured with an Atago refractometer at $21 \pm 1{ }^{\circ} \mathrm{C}$. The refractometer was calibrated against sucrose.

\section{Sensory analysis}

The juices and jellies were judged using quantitative sensory profiling (Stone et al. 1974), a 
Häkkinen, S. et al.: Sugars and organic acids in arctic bramble

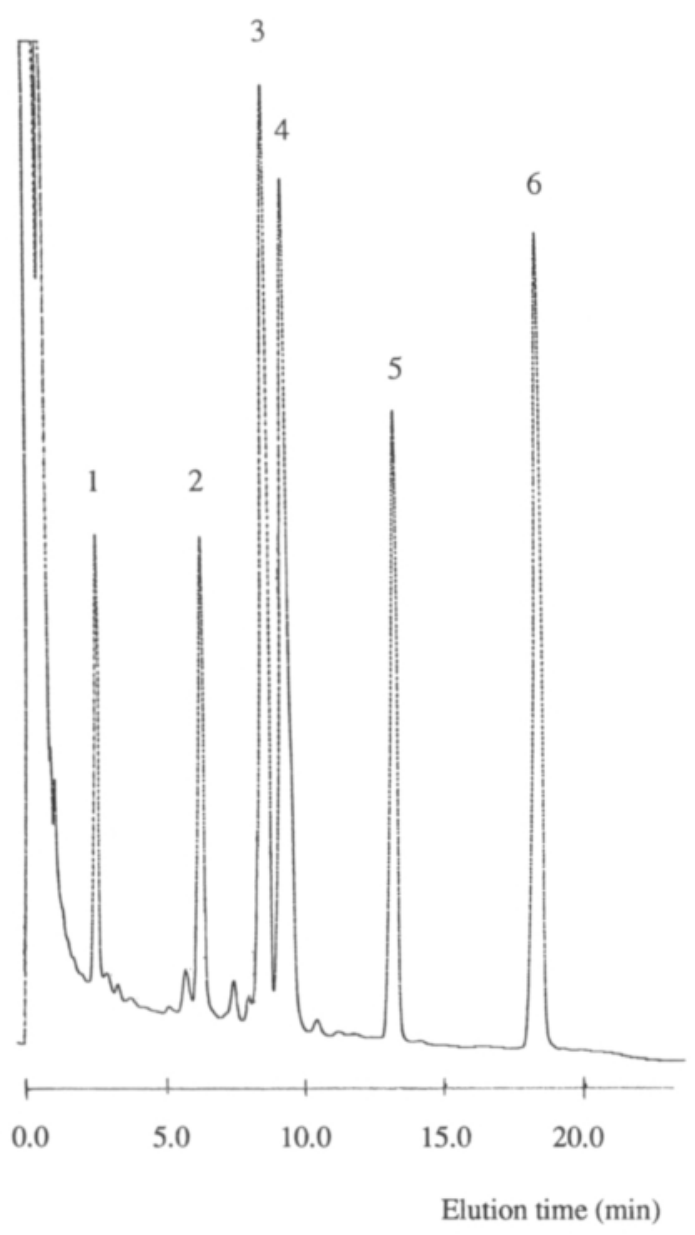

Fig.1. Gas chromatographic separation of sugars and organic acids in an arctic bramble sample (clone 050) in OV1 column. Peak identification: (1) malic acid, (2) citric acid, (3) fructose, (4) glucose, (5) internal standard (phenyl- $\beta$ D-glucopyranoside), (6) sucrose.

method that combines a descriptive analysis with an unstructured scale using a trained panel. The tests were done in normal white light in individual booths in a sensory laboratory. There was a sink and a tap in each booth for mouth rinsing and expectoration. The samples were coded with three-digit random numbers obtained from tables of random numbers. To start with, the sixmember panel suggested words to describe the juices and jellies. After a discussion, the quality attributes to be used in the analyses were select- ed. Six panelists were given three to five juices or jellies at a time in randomized order to be evaluated on an unstructured scale $(100 \mathrm{~mm})$ anchored from both ends with the attribute pairs chosen (e.g., not sweet taste - too sweet taste, not sour odour - too sour odour). In each session, first the odour (five odour attributes by smelling), and second the taste (eight taste attributes by tasting) of the samples were analysed. The approximate judgements were expressed by drawing a transverse line on the scale. There were no replications for the sensory analyses. The judgements were transformed to numeric values by measuring the distances of the lines from one end of the scale. The mean results for each attribute were calculated. The sensory profiles of the juices and jellies are thus based on the quality attributes chosen, and on the quantitation of these attributes by the scale. The profiles are presented graphically as radar figures.

At the end of each session, the panelists were asked to rank the juices or jellies according to their overall pleasantness. The best berry from each analysis was taken for a second round of sensory analysis. In this report, we concentrate on the results for odour and taste obtained from the last two evaluations, when the best juices and jellies were analysed.

\section{Results}

\section{Sugar and organic acid contents of arctic bramble and arctic bramble hybrid cultivars and clones}

In this study, sugars and organic acids were assayed on a total of 24 arctic bramble and arctic bramble hybrid cultivars and clones. Both sugars and acids were analysed in the same chromatographic run. A typical gas chromatogram is illustrated in Figure 1. The lower limit of quantification was $0.01 \mathrm{~g} / 100 \mathrm{~g}$, and the recoveries in the extraction method were $94-97 \%$ for sugars and $91-95 \%$ for acids. In summer 1993, the 
Vol. 4: 385-395.

Table 1. Sugar and organic acid contents of several cultivars and clones of arctic bramble cultivated in Finland in 1993.

\begin{tabular}{|c|c|c|c|c|c|c|c|}
\hline \multirow[b]{2}{*}{$\begin{array}{l}\text { Arctic bramble } \\
\text { cultivar/clone }\end{array}$} & \multicolumn{7}{|c|}{ Concentration $(\mathrm{g} / 100 \mathrm{~g}$ fresh wt.) } \\
\hline & Glucose & Fructose & Sucrose & Malic acid & Citric acid & $\begin{array}{c}\text { Sugars } \\
\text { analysed }\end{array}$ & $\begin{array}{c}\text { Acids } \\
\text { analysed }\end{array}$ \\
\hline 'Mespi' & 0,9 & 1.0 & 3,9 & 0,5 & 1.2 & 5,9 & 1,7 \\
\hline 'Pima' & 1,0 & 1,2 & 2,4 & 0,2 & 0,8 & 4,5 & 1,1 \\
\hline 004 & 1,0 & 1,3 & 3,1 & 0,4 & 1,5 & 5,4 & 1,9 \\
\hline 010 & 0,8 & 0,9 & 3,1 & 0,4 & 1,1 & 4,7 & 1,5 \\
\hline 021 & 1,1 & 1,3 & 1,8 & 0,3 & 1,4 & 4,3 & 1,8 \\
\hline 033 & 1,0 & 1,2 & 2.7 & 0,4 & 1,5 & 4,9 & 1,9 \\
\hline 039 & 0,5 & 0.6 & 2,6 & 0,3 & 1,5 & 3,8 & 1,8 \\
\hline 050 & 1.0 & 1,1 & 2,4 & 0,5 & 1,0 & 4,5 & 1,5 \\
\hline 055 & 0,8 & 0.9 & 2,9 & 0,4 & 0,7 & 4,6 & 1,1 \\
\hline 057 & 1,2 & 1,4 & 2,6 & 0,5 & 1,9 & 5,2 & 2,4 \\
\hline 075 & 0,8 & 0.9 & 3,8 & 0,3 & 1,1 & 5,5 & 1.4 \\
\hline 077 & 0,9 & 0,9 & 2,9 & 0,3 & 1,1 & 4,7 & 1.4 \\
\hline 078 & 0,9 & 0,5 & 3,2 & 0,3 & 1,1 & 4,6 & 1,4 \\
\hline 087 & 1,1 & 1,1 & 3,4 & 0,4 & 1,3 & 5,6 & 1,7 \\
\hline 096 & 1,3 & 1,5 & 3,3 & 0,4 & 1,7 & 6,1 & 2,1 \\
\hline 146 & 0,7 & 0,8 & 3,0 & 0,4 & 1,3 & 4,5 & 1,7 \\
\hline 178 & 0,9 & 0,9 & 3.2 & 0,2 & 0,9 & 5,0 & 1,1 \\
\hline 196 & 1,0 & 0,9 & 3,3 & 0.3 & 1,3 & 5.2 & 1,6 \\
\hline 212 & 0,8 & 0,9 & 3.2 & 0,2 & 0,8 & 4,8 & 1,0 \\
\hline Mean & 0,9 & 1,0 & 3,0 & 0,4 & 1,2 & 5,0 & 1,6 \\
\hline *SD & 0,2 & 0,3 & 0,5 & 0,1 & 0,3 & 0,6 & 0,4 \\
\hline${ }^{* *} \mathrm{CV}$ & 0.2 & 0,2 & 0,2 & 0,3 & 0,3 & 0,1 & 0,3 \\
\hline
\end{tabular}

sugar and organic acid contents of arctic bramble berries harvested at different dates in August were analysed. In a mixed, fresh 'Pima' and 'Mespi' sample, the content of organic acids (sum of malic and citric acids) was $1.8 \mathrm{~g} / 100 \mathrm{~g}$ at the beginning of August and below $0.8 \mathrm{~g} / 100$ $\mathrm{g}$ at the end of August. In the same samples, only a non-significant increase in sugar content was observed at the end of August ( $4.9 \mathrm{~g} / 100 \mathrm{~g}$ ) compared with the beginning of August (4.8 g/100 g). The sugar/acid ratio thereby increased over 2 -fold during the harvesting period.

The sugar and organic acid contents of the berries of the various arctic bramble and arctic bramble hybrids and clones are listed in Tables 1 and 2 . In all berries, sucrose was the main sugar. The average sugar contents of arctic brambles and arctic bramble hybrids were $5.0 \mathrm{~g} / 100 \mathrm{~g}$ and $4.7 \mathrm{~g} / 100 \mathrm{~g}$, respectively. In arctic brambles (Table 1), the highest sugar contents were detected in clone $096(6.1 \mathrm{~g} / 100 \mathrm{~g})$ and 'Mespi' $(5.9 \mathrm{~g} /$ $100 \mathrm{~g})$, and the lowest in clones 039 ( $3.8 \mathrm{~g} / 100$ g) and $021(4.3 \mathrm{~g} / 100 \mathrm{~g})$.

Of organic acids, malic and citric acids were separated and quantified. Citric acid was the predominant organic acid in all berries. The average organic acid contents (malic and citric acids) in arctic brambles and arctic bramble hybrids were $0.6 \mathrm{~g} / 100 \mathrm{~g}$ and $0.5 \mathrm{~g} / 100 \mathrm{~g}$, respectively. The sums of malic and citric acid contents (Table 1) were highest in arctic bramble clones $057(2.4 \mathrm{~g} / 100 \mathrm{~g})$ and $096(2.1 \mathrm{~g} / 100 \mathrm{~g})$, and lowest in clone $212(1.0 \mathrm{~g} / 100 \mathrm{~g})$.

The coefficient of variation $(\mathrm{CV})$ indicates 


\section{AGRICULTURAL SCIENCE IN FINLAND}

\section{Häkkinen, S. et al.: Sugars and organic acids in arctic bramble}
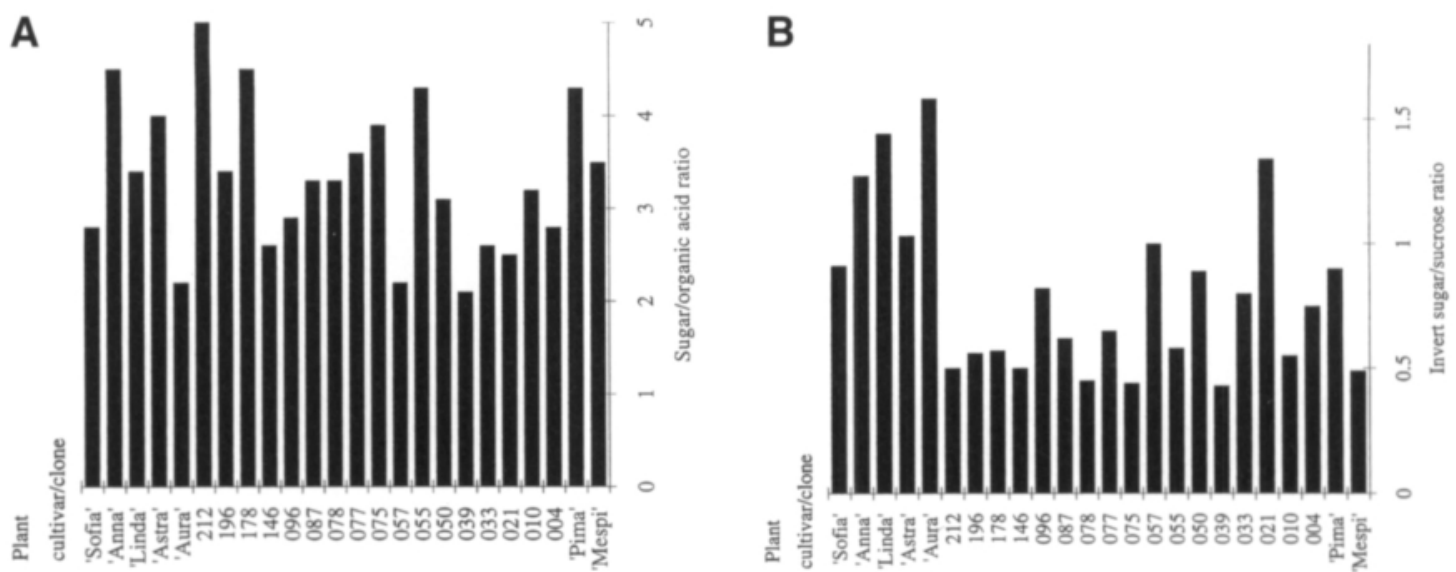

Fig. 2. Ratios of a) sugar/acid, and b) invert sugar/sucrose in arctic brambles and arctic bramble hybrids cultivated in Finland in 1993.

the variability in sugars and organic acids among the samples of different cultivars and clones (Tables 1 and 2). In arctic bramble, the CVs for three sugars and two organic acids were approximately $20 \%$ and $30 \%$, respectively. In arctic bramble hybrids, the CVs for three sugars and two organic acids were approximately $30 \%$ and $50 \%$, respectively. However, the CV's for the total sugars in arctic brambles and arctic bramble hybrids were approximately $10 \%$ and $20 \%$, respectively.

In the arctic bramble hybrids, the invert sugar/sucrose ratio was almost twice $($ mean $=1.3)$ that in arctic brambles (mean $=0.7$ ) (Fig. 2a). The values for invert sugar/sucrose ratios in the arctic bramble cultivars and clones were between 0.4 (clone 075) and 1.3 (clone 021), and in the arctic bramble hybrid cultivars between 0.9 ('Sofia') and 1.6 ('Aura'). The sugar/organic acid ratios were between 2.1 (clone 039) and 5.0 (clone 212) in the arctic bramble cultivars and clones (mean $=3.3$ ) and between 2.2 ('Aura') and 4.5 ('Anna') in the arctic bramble hybrid cultivars $($ mean $=3.4)$ (Fig. 2b).

Table 2. Sugar and organic acid contents of arctic bramble hybrid cultivars grown in Finland in 1993.

\begin{tabular}{|c|c|c|c|c|c|c|c|c|}
\hline \multirow{2}{*}{\multicolumn{2}{|c|}{$\begin{array}{l}\text { Arctic bramble } \\
\text { hybrid/cultivar }\end{array}$}} & \multicolumn{7}{|c|}{ Concentration ( $\mathrm{g} / 100 \mathrm{~g}$ fresh wt.) } \\
\hline & & Glucose & Fructose & Sucrose & Malic acid & Citric acid & $\begin{array}{c}\text { Sugars } \\
\text { analysed }\end{array}$ & $\begin{array}{c}\text { Acids } \\
\text { analysed }\end{array}$ \\
\hline \multirow{8}{*}{$\begin{array}{l}\text { 'Aura' } \\
\text { 'Astra' } \\
\text { 'Linda' } \\
\text { 'Anna' } \\
\text { 'Sofia' }\end{array}$} & & 1,7 & 1,8 & 2,2 & 0,7 & 1,9 & 5,7 & 2,6 \\
\hline & & 1,4 & 1,4 & 2,7 & 0,4 & 1,0 & 5,6 & 1,4 \\
\hline & & 1,4 & 1,6 & 2,1 & 0,4 & 1,2 & 5,1 & 1,5 \\
\hline & & 1,0 & 1,0 & 1,6 & 0.1 & 0,7 & 3,6 & 0,8 \\
\hline & & 0,8 & 0,9 & 1.8 & 0,4 & 0,8 & 3,4 & 1,2 \\
\hline & Mean & 1,3 & 1,4 & 2,1 & 0,4 & 1,1 & 4,7 & 1.5 \\
\hline & *SD & 0,4 & 0,4 & 0,4 & 0,2 & 0,5 & 1,1 & 0,7 \\
\hline & $* * \mathbf{C V}$ & 0.3 & 0,3 & 0,2 & 0,5 & 0,4 & 0,2 & 0,5 \\
\hline
\end{tabular}

*SD $=$ Standard deviation

${ }^{* *} \mathrm{CV}=$ Coefficient of variation 
Vol. 4: 385-395.

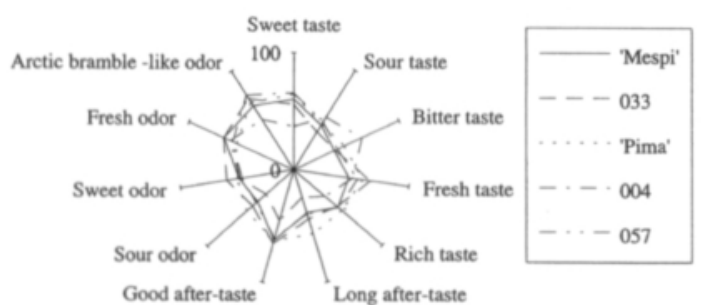

Fig. 3. Profiles of sensory evaluation of taste and odour for juices made from arctic bramble cultivars and clones ('Mespi', 'Pima', clones 004, 033 and 057).

\section{Sensory evaluation of juices and jellies}

In the juices, the $\mathrm{pH}$ varied between 3.0 and 3.1 and soluble solids between 10 and $11^{\circ}$ Brix (Table 3). Profiles for the sensory evaluations of taste and odour of juices and jellies from the best arctic bramble cultivars and clones are presented in Figures 3 and 4. There were no great differences in the tasted sweetness among the juices, except for clone 057 which was clearly evaluated as the least sweet (Fig. 3). The juice from clone 057 was evaluated as the most sour in taste, and the juice from clone 033 as the least sour, although the differences were not great. The odour was judged sweetest in juice prepared from clone 033; all other cultivars and clones were judged to be more or less equal to each other in sweetness of odour. The odour of the juice from 'Pima' was judged to be the most sour and that of the juice from clone 004 the least sour.

Table 3. Soluble dry matter $\left({ }^{\circ} \mathrm{Brix}\right)$ and $\mathrm{pH}$ of juices used for sensory analyses as measured before addition of sucrose solution.

\begin{tabular}{lcc}
\hline $\begin{array}{l}\text { Arctic bramble clone/ } \\
\text { cultivar }\end{array}$ & ${ }^{\circ}$ Brix & $\mathrm{pH}$ \\
\hline 'Mespi' & 11,0 & 3,06 \\
'Pima' & 10,5 & 3,01 \\
004 & 10,0 & 3,10 \\
021 & 10,5 & 3,06 \\
033 & 11,0 & 3,03 \\
039 & 11,0 & 3,08 \\
057 & 10,5 & 3,10 \\
\hline
\end{tabular}

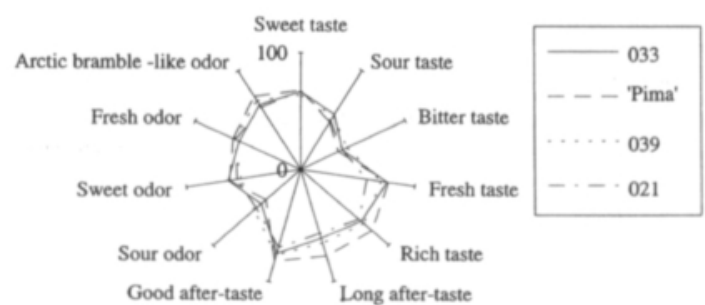

Fig. 4. Profiles of sensory evaluation of taste and odour for jellies made from arctic bramble cultivar and clones ('Pima', clones 033,039 and 021 ).

The sensed sweetnesses of the taste and odour of the best jellies ('Pima', clones 033, 021 and 039) were similar, as were the sensed sournesses of the jellies (Fig. 4).

\section{Discussion}

\section{Sugars and organic acids in arctic bramble and its hybrids}

We show here that sugar and organic acid contents vary among different cultivars and clones of arctic bramble and arctic bramble hybrid. Kallio et al. (1985) made a similar observation on several strains, cultivars and hybrids of arctic bramble. In our study, the sugar content of arctic bramble berries was lower (3.8-6.1 g/100 g) than in the above study $(6.5-10.1 \mathrm{~g} / 100 \mathrm{ml})$ (Kallio et al. 1985). We noted a small decrease in sugars caused by genes from Alaskan arctic bramble in the arctic bramble hybrid (3.4-5.7 g/ $100 \mathrm{~g}$ ), but the decreasing effect was not as strong as that reported by Kallio et al. (1985) (4.9-7.6 g/100 g). In our study, organic acid contents in arctic bramble cultivars and clones ranged from 1.0 to $2.4 \mathrm{~g} / 100 \mathrm{~g}$, and these results agree well with those of Kallio et al. (1985) (1.1$2.7 \mathrm{~g} / 100 \mathrm{ml})$. The organic acids are important in forming conjugates with anthocyanins, thereby stabilizing the colour of food products such as juices, wines and jellies (Brouillard et al. 1989). 


\section{AGRICULTURAL SCIENCE IN FINLAND}

Häkkinen, S. et al.: Sugars and organic acids in arctic bramble

Varietal differences in sugar contents have also been reported for strawberry (Skrede 1982). In addition to plant cultivar and the ripeness of the berries, conditions such as temperature during ripening, storage and transportation may affect the sugar and organic acid contents of berries and fruits. The observed decline in the total organic acid content of the mixed 'Pima' and 'Mespi' samples during the harvesting period in August 1993 is consistent with the finding of Burton (1982) that the acidity of many fruits, e.g. apples and strawberries, decreases during the harvesting period.

The average sucrose content was almost twice as high in the arctic brambles studied here, as in strawberries cultivated in Finland (Haila et al.1992b). On the other hand, the glucose and fructose contents of arctic bramble were approximately half of those in strawberry. The malic acid content was about the same in both berries, but the citric acid content of arctic bramble was twice as high as that of strawberry. In black currant, the amount of sucrose was less than one third and in red currant one thirtieth of that in the arctic brambles we studied (Haila et al. 1992b). However, the contents of total sugars (fructose, glucose and sucrose) in black currant and red currant were 5.41 and $4.41 \mathrm{~g} / 100 \mathrm{~g}$, respectively. According to Souci et al. (1981), black currant, red currant and bilberry all contained higher amounts of total sugars than arctic bramble: $6.99,5.61$ and $5.84 \mathrm{~g} / 100 \mathrm{~g}$, respectively. The contents of reducing sugars in highbush blueberry ( 6.8 and $7.7 \mathrm{~g} / 100 \mathrm{~g}$ ) were higher than in arctic bramble; however, the sucrose content was much lower $(0.15-1.02 \mathrm{~g} / 100 \mathrm{~g})$ than in arctic bramble (Kader et al. 1994). In lingonberry, the total sugar content $(3.93 \mathrm{~g} / 100 \mathrm{~g})$ was lower than in arctic bramble (Souci et al. 1981). In raspberry, the average content of total sugars (sucrose, fructose and glucose) has been reported to be $5.82 \mathrm{~g} / 100 \mathrm{~g}$ (Wrolstad \& Shallenberger 1981), which is higher than that in the arctic brambles studied here. Our observation that the $\mathrm{CVs}$ for different sugars varied more than did the $\mathrm{CV}$ for total sugars is probably due to enzymatic hydrolysis of sucrose to fructose and glucose during thawing of the berry samples (Skrede 1983).

Marked differences in the invert sugar/sucrose ratios between arctic bramble and arctic bramble hybrids were noted in the present study. A higher invert sugar/sucrose ratio in arctic bramble hybrids than in arctic brambles was also observed by Kallio et al. (1985). This finding together with differences in the contents of aroma compounds (Larsson 1969, Hiirsalmi et al. 1974, Kallio et al. 1980), may partly explain the differences in aroma between arctic bramble and arctic bramble hybrids. According to Sostrunk and Morris (1985), an important role of sugars and organic acids is to contribute to the taste of berries. That fructose is sensed almost twice as sweet as sucrose (Schiweck 1971) is also of importance when considering the effect of different types of sugar on the sensory properties of berries. The relative sweetness of sugars, especially fructose, is also highly dependent on temperature.

The sugar/acid ratio of the samples studied ranged from 2.1 to 5.0. The mean sugar/organic acid ratio was about the same for arctic brambles and arctic bramble hybrids. Kallio et al. (1985) reported a range of 2.5-5.9 in the sugar/ acid ratio of arctic bramble and arctic bramble hybrid samples. The sugar/acid ratio was lowest (2.5) in berries of Alaskan arctic bramble, and highest in the arctic bramble cultivars 'Pima' and 'Mespi' (5.3-5.9). No such difference was noted here,

\section{Sensory evaluations compared with chemical analyses}

Tables 1-3 and Figure 2 give basic figures for the natural variation in the chemical parameters measured on the berries of arctic bramble and hybrids. Sensory evaluations revealed differences among the berry cultivars and clones, but only in some cases were the differences marked (Figs 3 and 4). The sensory analyses should have been repeated for statistical significance. Unfor- 


\section{AGRICULTURAL SCIENCE IN FINLAND}

Vol. 4: 385-395.

tunately, however, there were not enough berries, and the results are based on single analyses.

Among the arctic bramble juices, clone 057 was tasted the most sour and the least sweet. The sugar/acid ratio in this clone was lower than that in the other four clones and cultivars sensorially tested. The total organic acid content was also highest in clone 057. Differences in the sensed sweetness and sourness of taste and odour were smaller among the clones and cultivars judged best as jellies than among the clones and cultivars judged best as juices. One reason for this discrepancy could be that whereas $30 \%$ sugar was added to jellies, only $10 \%$ sugar was added to juices. There were, however, some differences in the sourness of the taste. The jelly made from clone 039 was judged to be the most sour in taste, and the sugar/acid ratio in this clone was also the lowest of all the arctic bramble clones and cultivars analysed. The jelly made from clone 039 was judged to be the most sour and least sweet in odour, too.

No clear correlation is seen between the results of the sensory and chemical analyses, possibly because the chemical analyses were made on berries and the sensory analyses on juices and jellies with a higher sucrose content. The berries are not usually consumed fresh because of the strongly bound plug. In some clones, however, the sugar/acid ratio had an effect on the sensed sweetness and sourness. Skrede (1980), in contrast, did not find any significant correlation between the sensory parameters and chemical analyses for sourness and sweetness when analysing twelve strawberry varieties. According to Kallio et al. (1980), the content of the aroma compound 2,5-dimethyl-4-hydroxy $3(2 \mathrm{H})$-furanone describes well the intensity of the odour $(r=0.867, p=0.003)$ but somewhat less well the character $(r=0.821, \mathrm{p}=0.006)$ and overall impression of the odour $(\mathrm{r}=0.751, \mathrm{p}=0.016)$ in arctic bramble juices.

The juices and jellies were ranked according to their overall pleasantness. Of the arctic bramble clones and cultivars, especially 'Mespi', clone 033 and 'Pima' proved to be good as juices. The arctic bramble hybrid 'Aura' was not suitable for juice making because of its poor colour, aroma and acidity as juice. As a jelly, though, 'Aura' was ranked among the best varieties, right after clone 033 and 'Pima'.

The results of this study should be useful for berry breeders developing new arctic bramble and arctic bramble hybrid cultivars. The data can also be used to describe the phenotypes of new berry varieties. The findings should also interest the food industry, as it needs information on the differences in organic acid and sugar contents between different arctic bramble and hybrid cultivars in order to improve the preservation of juices and jellies (Skrede 1980). The wine industry, too, needs the information for controlling fermentation processes and stabilizing the colour of wines (Peynaud 1989).

Acknowledgements. We wish to express our gratitude to Mrs Taina and Mr Risto Hallman (Alahovin Puutarha Oy) for preparing the juices and jellies and for serving as panelists in the sensory evaluations. We also thank Mr Ilpo Nylund (Lignell \& Piispanen, Oy Gust. Ranin) for serving as a panelist in the sensory evaluations. We are grateful to the Ministry of Education of Finland for financing the study.

\section{References}

Brouillard, R., Mazza, G., Saad, Z., Albrecht-Gary, A.M. \& Cheminant, A. 1989 . The copigmentation reaction of anthocyanine: A Micro-probe for the structural study of aqueous solutions. Journal of the American Chemical Society 111: 2604-2610.
Burton, W.G. 1982. Postharvest physiology of food crops. Longman, New York. 339 p.

Haila, K., Kumpulainen, J., Häkkinen, U. \& Tahvonen, R. 1992a. Sugar and organic acid contents of vegetables consumed in Finland during 1988-1989. Journal of 
Häkkinen, S. et al.: Sugars and organic acids in arctic bramble

Food Composition and Analysis 5: 100-107.

-, Kumpulainen, J., Häkkinen, U. \& Tahvonen, R. $1992 b$. Sugars and organic acids in berries and fruits consumed in Finland during 1987-1989. Journal of Food Composition and Analysis 5: 108-111.

Hiirsalmi, H., Kallio, H., Pyysalo, T., Linko, R. \& Koponen, P. 1974. The ionone content of raspberries, nectarberries and nectar raspberries and its influence on their flavour. Annales Agriculturae Fenniae 13: 23-29.

- \& Säkö, J. 1980. Hybrids of the arctic bramble species (Rubus stellatus $\times$ R. arcticus). Acta Horticulturae 112: 103-106.

-, Junnila, S. \& Säkö, J. 1987. 'Aura' and 'Astra', Finnish arctic bramble hybrid varieties. Annales Agriculturae Fenniae 26: 261-269.

Kader, F., Rovel, B., Girardin, M. \& Metche, M. 1994. Composition of the fruit of highbush blueberry (Vaccinium corymbosum L.) grown in the East of France (Vosges). Sciences Des Aliments 14: 281-290.

Kallio, H. 1975. Chemical constituents of the volatile aroma compounds in Rubus arcticus L. subsp. stellatus (Sm.) Boivin, with reference to Rubus arcticus L. subsp. arcticus. Report of Kevo Subarctic Research Station 12: 60-65.

- 1976a. Identification of vacuum steam-distilled aroma compounds in the press juice of arctic bramble, Rubus arcticus L. Journal of Food Science 41: 555-662.

- 1976b. Development of volatile aroma compounds in arctic bramble, Rubus arcticus L. Journal of Food Science 41: 563-566.

- \& Honkanen, E. 1974. An important major aroma compound in arctic bramble, Rubus arcticus L. Proceedings of International Congress in Food Science and Technology IV. 1: 84-92.

-, Linko, R.R., Pyysalo, T. \& Puntari, I. 1978. Identification of keto acids in arctic bramble, $R$. arcticus $\mathrm{L}$. as methyl esters of their 2,4-dinitrophenylhydrazones. Analytical Biochemistry 90: 359-364.

-, Laine, M. \& Huopalahti, R. 1980. Aroma of the berries of the hybrid Rubus stellatus $\mathrm{Sm} . \times \mathrm{R}$. arcticus $\mathrm{L}$. Report of Kevo Subarctic Research Station 16: 17-22. -, Lapveteläinen, A., Hirvi, T. \& Honkanen, E. 1984. Volatiles in relation to aroma in the berries of Rubus arcticus. In: Schreier P. (ed.). Analysis of volatiles. Proceedings of International Workshop Wurtzburg, Federal Republic of Germany, September 20th-30th, 1983. p. 433446.

-, Lehtismäki, A., Linko, R. \& Dalman, P. 1985. Sugars and acids as characteristics of the arctic bramble, Rubus arcticus L. Proceedings of European Food Chemistry III. Antwerp, Belgium. p. 325-330.

Kangasjärvi, J. \& Oksanen, J. 1989. Pollinator behaviour in cultivated and wild arctic bramble (Rubus arcticus L.). Journal of the Agricultural Science in Finland 61: 33-38.

Kotimäki, M. \& Hiirsalmi, H. 1979. Cytogenetic studies on Rubus arcticus, Rubus stellatus and their hybrids. Hereditas 91: 83-89.

Larsson, E.K.G. 1969. Experimental taxonomy as a base for breeding in northern Rubi. Hereditas 63: 283-351. - 1970. Development and cultivation of northern small fruits in the genus Rubus L. Ph.D. thesis, Uppsala Landsbrukshőgskolan, Uppsala, Sverige.

Li, B. W. \& Schuhmann, P.J. 1980. Gas-liquid chromatographic analysis of sugars in ready-to-eat breakfast cereals. Journal of Food Science 45: 138-141.

Peynaud, E. 1989. Knowing and making wine. John Wiley \& Sons, USA. 391 p.

Pyysalo, T., Suihko, M. \& Honkanen, E. 1977. Odour thresholds of the major volatiles in cloudberry (Rubus chamaemorus, L.) and arctic bramble (Rubus arcticus, L.). Lebensmittel -Wissenschaft \& Technologie 10: 3640.

Ryynänen, A. 1972. Arctic bramble (Rubus arcticus L.) a new cultivated plant. Annales Agriculturae Fenniae 11: 170-173.

- 1973. Rubus arcticus L. and its cultivation. Annales Agriculturae Fenniae 12: 1-76.

Ryynänen, A. \& Dalman, P. 1983. A new variety of arctic bramble 'Pima'. Annales Agriculturae Fenniae 22: 17.

Schiweck, H. 1971. Chemische und physikalische Eigenschaften von Zuckern, Zuckeralkoholen und Calciumsaccharosephosphat. Deutsche Zahnärtzliche Zeitschrift 26:1063-1078.

Sistrunk, W.A. \& Morris, J.R. 1985. Strawberry quality: Influence of cultural and environmental factors. In: H.E. Patee (ed.). Evaluation of quality of fruits and vegetables. AVI, Westport. p. 217-256.

Skrede, G. 1980. Strawberry varieties for industrial jam production. Journal of the Science of Food and Agriculture 31: 670-676.

- 1982. Quality characterization of strawberries for industrial jam production. Journal of the Science of Food and Agriculture 33: 48-54.

- 1983. Changes in sucrose, fructose and glucose content of frozen strawberries with thawing. Journal of the Food Science 48: 1094-1096.

Souci, S.W., Fachmann, W. \& Kraut, H. 1981. Die Zusammensetzung der Lebensmittel - Năhrwert-TabelIen 1981/82. Wiss. Verlagsges., Stuttgart. 279 p.

Stone, H., Sidel, J.L., Oliver, S., Woolsey, A. \& Singleton, R.C. 1974. Sensory evaluation by quantitative descriptive analysis. Food Technology 28: 24-34.

Tammisola, J. 1988. Incompatibility classes and fruit set in natural populations of arctic bramble (Rubus arcticus L.) in Finland. Journal of Agricultural Science in Finland 60: 327-446.

- \& Ryynänen, A. 1970. Incompatibility in Rubus arcticus L. Hereditas 66: 269-278.

Ulrich, R. 1970. Organic acids. In: A.C. Hulme (ed.). The biochemistry of fruits and their products. Academic Press, London. p. 89-118.

Wrolstad, R.E. \& Shallenberger, R.S. 1981. Free sugars and sorbitol in fruits - A compilation from the literature. Journal of the Association of Official Analytical Chemists 64: 91-103. 
Vol. 4: 385-395.

\title{
SELOSTUS
}

\section{Eräiden mesimarja- ja jalomaarainlajikkeiden ja -kantojen sokerit ja orgaaniset hapot. Mesimarjalajikkeista ja -kannoista valmistettujen mehujen ja hyytelöiden aistinvarainen arviointi.}

\author{
Sari Häkkinen, Harri Kokko, Sirpa Paasisalo ja Sirpa Kärenlampi \\ Kuopion yliopisto
}

Suomessa viljellään mesimarjaa (Rubus arcticus L.) ja jalomaarainta (Rubus arcticus L. nothosubsp. stellarcticus $\mathrm{G}$. Larsson), ja erityisesti mesimarja on haluttu raaka-aine elintarvike- ja viiniteollisuudessa. Tämän tutkimuksen tavoitteena oli analysoida kaasukromatografisesti tärkeimmät sokerit ja orgaaniset hapot 19 mesimarjalajikkeesta tai -kannasta ja 5 jalomaarainlajikkeesta. Marjojen tärkein sokeri oli sakkaroosi, ja tärkein orgaaninen happo sitruunahappo. Marjojen sokeri- ja orgaanisten happojen pitoisuudet vaihtelivat eri lajikkeilla ja kannoilla. Keskimääräinen mesimarjojen sokeripitoisuus oli 5,0 g (vaihteluväli $3,8-6,1 \mathrm{~g}$ ) ja jalomaarainlajikkeiden $4,7 \mathrm{~g}$ (vaihteluväli $3,4-5,7 \mathrm{~g}$ ) $100 \mathrm{~g}$ :ssa tuoreita marjoja. Keskimääräinen happopitoisuus oli mesimarjoissa
$0,6 \mathrm{~g}$ ja jalomaaraimissa $1,5 \mathrm{~g} 100 \mathrm{~g}$ :ssa tuoreita marjoja.

Sokereiden ja orgaanisten happojen muutoksia tutkittiin satokauden aikana kahden mesimarjalajikkeen sekanäytteiden avulla. Lisäksi tutkittiin eräistä mesimarjalajikkeista ja -kannoista valmistettujen mehujen ja hyytelöiden aistinvaraisia ominaisuuksia kuvailevalla analyysilla. Mehuiksi tai hyytelöiksi valmistettujen mesimarjojen aistitun makeuden tai happamuuden ja kemiallisesti määritettyjen sokeri- ja happopitoisuuksien välillä ei ollut selvää riippuvuutta. Saatuja tuloksia voivat hyödyntää marjojen jalostajat, tuotekehittäjät elintarviketeollisuudessa sekä marjanviljelijät. 